University of Nebraska - Lincoln

DigitalCommons@University of Nebraska - Lincoln

1995

\title{
Water Runoff Monitoring in Arid Areas Using Integrated Remote Sensing and GIS Techniques
}

G. G. Lemoine

Synoptics

Anatoly A. Gitelson

University of Nebraska - Lincoln, agitelson2@unl.edu

E. Adar

Ben Gurion University

J. G.M. Bakker

Synoptics

Follow this and additional works at: https://digitalcommons.unl.edu/natrespapers

Part of the Natural Resources and Conservation Commons

Lemoine, G. G.; Gitelson, Anatoly A.; Adar, E.; and Bakker, J. G.M., "Water Runoff Monitoring in Arid Areas Using Integrated Remote Sensing and GIS Techniques" (1995). Papers in Natural Resources. 236.

https://digitalcommons.unl.edu/natrespapers/236

This Article is brought to you for free and open access by the Natural Resources, School of at DigitalCommons@University of Nebraska - Lincoln. It has been accepted for inclusion in Papers in Natural Resources by an authorized administrator of DigitalCommons@University of Nebraska - Lincoln. 


\title{
Water Runoff Monitoring in Arid Areas Using Integrated Remote Sensing and GIS Techniques
}

\author{
G.G. Lemoine' ${ }^{1}$ A. Gitelson ${ }^{2}$, E. Adar ${ }^{3}$ and J.G.M. Bakker ${ }^{1}$ \\ 1 SYNOPTICS, P.O. Box 117, 6700 AC Wageningen, the Netherlands \\ T: +31 8370 26936, F: +318370 25705, E: xsynoptics01@rcl.wau.nl \\ 2 Ben Gurion University, Remote Sensing Laboratory, Sede Boker, Israel \\ ${ }^{3}$ Ben Gurion University, Water Resources Research Centre, Sede Boker, Israel
}

\begin{abstract}
Our paper discusses the proposed methodology for the implementation of a monitoring tool for surface water run-off in (semi-)arid areas. This tool is being developed as part of a two year multi-disciplinary shared cost project supported by the European Union AVICENNE initiative. The tool aims at supporting decision making and planning in water run-off management for sustainable development of water resources for human settlement and regeneration of desertification-prone areas in the arid climate zone.
\end{abstract}

The initial phase of the project (1995) consists of the testing of various remote sensing products for DTM generation and surface characterization. Both SPOT stereo pairs and interferometric ERS-1 SAR products will be assessed on their potential to generate useful DTM information over the study area. SPOT spectral data and multi-temporal ERS-1 backscattering signatures will be used to characterize local vegetation covers, surface type and moisture contents.

Remote sensing data and extensive ground truth data are combined with a hydrological network model in a geographical information system. The design of the GIS will be intended to both support algorithmic combination of the various input layers and to generate thematic end products in support of the monitoring and planning of selected watersheds. The GIS will also form the interface to the enduser.

Our paper will describe executed and planned activities in the first phase of the project and will show some initial results.

keywords: runoff, arid areas, SAR, INSAR, SPOT, DTM, bydrology

\section{INTRODUCTION}

With the growing population pressure in the Maghreb and Middle Eastern countries around the Mediterranean Sea the sustainability of human settlement in these (semi-) arid areas ultimately depends on the development of alternative sources of drinking-water and industrial water supplies. Appropriate conservation management of surface run-off water seems, in this respect, a feasible alternative to the irreversible depletion of deep aquifers. In addition, extended areas in this region are prone to desertification. Some global climatic change studies predict desertification to proceed significantly into areas that are, at present, still in agricultural use. Apart from potential losses in agricultural production, the desertification is likely to result in mounting population pressure on the already stressed population centres. Again, the need for management of the scarce water resources in the area is crucial to reverse this process.

The characterization of large watersheds in (semi-) arid areas is the central source of information for any decision policy in long-term surface water resources management [1]. The local topography and the physical characteristics of the surface (e.g. roughness, soil hydraulic parameters), the extent, type and dynamic behaviour of the vegetation cover at local and regional scale, and the frequency and intensity of precipitation events form the input to hydrological models which can be utilized to predict surface runoff water harvesting in areas of interest.

Traditionally, watershed characterization has been carried out in well known areas of limited extent. With the advent of advanced remote sensing techniques, the possibility exists to extrapolate existing knowledge on those watersheds to significantly larger areas. Furthermore, remotely sensed data can be utilized to identify additional areas of interest for further study, and thus optimize data collection programs and techniques. In the current context, both optical remote sensing products (e.g. SPOT or LANDSAT) and active microwave instruments (ERS-1 SAR) are useful to monitor surface conditions, geomorphology, and vegetation cover over the study area. The fusion of the various data sources with hydrological models can then yield more accurate estimates of water harvesting during and after periods of rain.

\section{METHODOLOGY}

\section{Hydrological model}

To model surface run-off and water discharge of large watersheds, the total area is divided in a grid of elementary surface elements. For each surface grid cell the local slope can be derived, for instance from a digital terrain model (DTM). With the known geomorphologic, surface and vegetation characteristics, derived from remote sensing data and ground measurements, a run-off efficiency factor can be attributed to each grid cell. The total runoff is than calculated from a set water discharge budget equations for an ensemble of adjacent grid cells [2].

\section{Digital Terrain Model generation}


A first prerequisite in the project is the availability of a digital terrain model (DTM). The possibility to derive DTMs from remote sensing systems is of particular interest for unknown areas.

We will compare the DTM quality from both a SPOTstereo-pair and a pair of interferometric ERS-1 SAR images with information derived from available topographical maps. Both technical and economic factors will be considered in the final product evaluation. Apart from the slope and topographical height information necessary for the hydrological model, DTMs will be used for accurate coregistration of remote sensing imagery as well as image intensity corrections of slopy terrain [3]. The DTM constitutes one of the most important information layers in the final GIS.

\section{Remote sensing algorithms}

Since periods of rain will typically lead to local outburst of vegetation growth, and sometimes to changes in the surface characteristics (for instance due to erosion), the watershed must be treated as a dynamic system. This implies that a multi-temporal approach must be adopted to accurately predict the behaviour of the watershed over time.

Remote sensing data are assumed to provide the information on the characteristics of the grid cell, the basic unit in the hydrological model. SPOT and LANDSAT data will be available directly before and after the rain season, in order to monitor local vegetation development. For SPOT/LANDSAT data, we have local radiometric data available for atmospheric correction. We will test various vegetation index algorithms on the data. Similar indices will be developed and tested to discriminate various surface types and geological formations (for instance, alluvium/collovium delineation).

Since SAR instruments have all weather capability, data will also be acquired during the rain season. From SAR intensity data, surface roughness and surface wetness can be derived with the help of microwave backscattering models. In reliefed areas, SAR data must be corrected for the local slope. The by-product of SAR interferometry, the scene coherency image, contains further information on terrain dynamics.

Results from remote sensing data analysis form additional input and output data layers in the GIS, typically as thematic maps.

\section{Ground data collection}

In support of the sensitivity analysis and remote sensing data analysis, it is necessary to collect additional ground observations on characteristics and processes that are not already known from existing data resources (e.g. geological and hydrological maps).

Anticipated steady-state (i.e. slowly or non-changing) parameters will, typically, include surface roughness, infiltration rates, erosion sensitivity and soil salinity. Measurement techniques include surface profile measurements, and various laboratory techniques, for instance, rain simulator experiments to characterize infiltration. Mapping of surface types, occurrence of vegetation and other characteristic terrain elements will also be part of ground data collection (using calibrated field photography in combination with detailed measurements).

On the days of SPOT/LANDSAT acquisition, field measurements with various radiometer systems and sun photometers will be carried out in support of data calibration. Soil moisture measurements around SAR acquisition times during the rain period will be part of ground data collection. Meteorological data will be available for the rain periods.

For detailed analysis of the accuracies of the generated DTMs it is necessary to measure in some baselines with ground based surveying methods (theodolite or GPS systems). These baselines are further used to relate the relative terrain heights in the remote sensing imagery to true ground level.

\section{GIS design}

In the GIS, those data products and processing algorithms that are necessary to generate water harvesting forecasts are integrated. In general, vector products (maps), raster data (remote sensing data) and points measurements (ground data) will have to be combined in the GIS. Algorithmic combination of various input layers, e.g. the hydrological model, will lead to output products which can be used in watershed monitoring. Especially the multi-temporal approach sets high quality requirements for ease of update, backlogging and data storage. Furthermore, the GIS, being the interface to the end-user, plays a central role in the knowledge transfer on the methodology to third parties. Therefore, its development will ask for a close interaction between the designers and the end-users.

An open design of the planning tool based on the GIS, would allow relatively simple extensions into other applications areas, such as agro-meteorological modelling, regional scale climatological change monitoring, etc..

\section{MATERIAL}

\section{Selection of the study sites}

As principal study area, the North-central part of the Negev Desert in Israel has been chosen (a 50 by 50 square kilometres area with its centre at Sede Boker, approximately at $30^{\circ} 50^{\prime} \mathrm{N}$ and $35^{\circ} 45^{\prime} \mathrm{E}$ ). The location of the Negev test site is illustrated in Fig 1.

The test site has been chosen for the following reasons:

1. The Negev Desert area is a typical resettlement area, and highly illustrative for the general settlement problems in other arid areas in the region.

2. The area is in the transition zone between the semi-arid and arid climate types. Several large watersheds are located in the test area which are ideal for the intended research. Furthermore, the area is representative for the (semi-) arid areas in other countries in the region. Results 
from the study should, therefore, be easily transferable to other users.

3. Large parts of the area have already been subject to hydrological studies. Thus, a large volume of ground data are already available. Also, some historical remote sensing data sets are already available.

4. The area can be easily reached by road; the watersheds for detailed research are within minutes travelling from the Sede Boker Campus of Ben Gurion University.

\section{Remote Sensing data}

For the test sites, we have some older SPOT and ERS-1 data available $(1991,1992)$ which we will be using to access some generic features and to improve resolution or reduce SAR speckle. Fig. 2 shows a 100-m resolution ERS-1 image of the study area.

A LANDSAT scene has been ordered for March 29, 1995 , to study the extent of vegetation development in the spring season, and allow better separation of surface classes due to higher spectral resolution.

At this time of writing, we are in the process of ordering SAR SLC image pairs for interferometric DTM generation. From phase D of the ERS- 1 cycle, we have a chance to order ERS-1 image pairs with a temporal separation of 6 to 12 days, with perpendicular baselines ranging from 8 to 300 meters. Some further checking of rain records is necessary before the data can be ordered.

Later in the project, we hope to include data from the SIR-C and J-ERS-1, through cooperation with other research groups. In the winter season $1995 / 96$ we plan to collect a full set of seasonal remote sensing data to test the pre-operational functioning of our evaluated hydrological GIS.

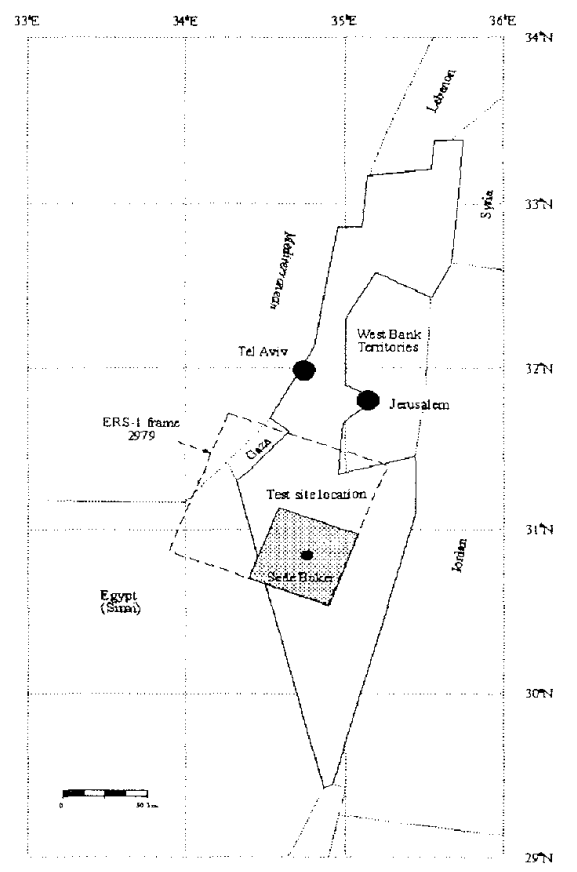

Figure 1. Approximate location of the Negev test site.

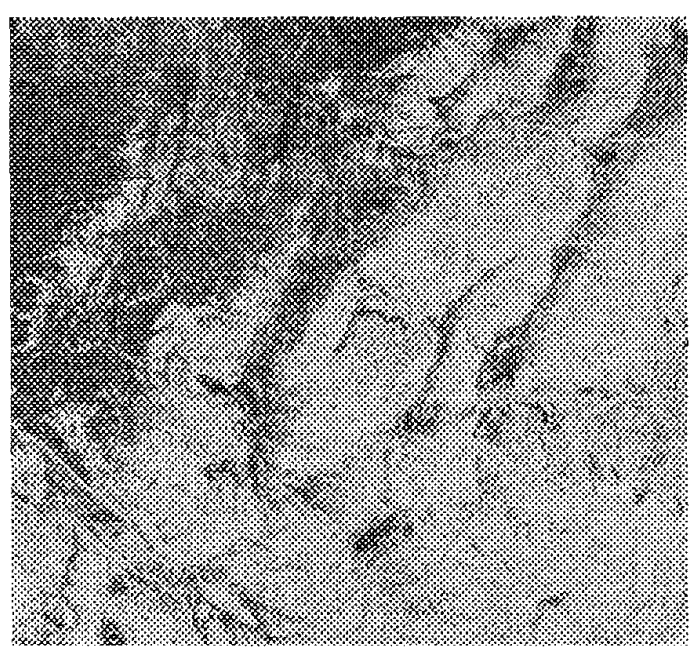

Figure 2. ERS-1 low resolution image of the central Negev desert. The study site is located in the lower right quadrant of the image (C ESA, 1991).

\section{CONCLUSIONS}

We have started the AVICENNE project with an inventory of existing data and ordering of remote sensing training data sets. Initial results will be shown at the Symposium. The purpose of this paper was to introduce our methodology and discuss the data sets we will be using.

We are currently discussing the enhancement of the project with other groups and are looking for contacts to extent the use of the methodology to related research subjects, such as desertification and erosion studies, climatological modelling and desert research.

\section{ACKNOWLEDGMENT}

This work is carried out under contract 93AVI143 between the European Commission, AVICENNE Initiative, DG XII, B-4 Brussels and SYNOPTICS, Integrated Remote Sensing and GIS Applications of Wageningen, the Netherlands. BGU-RSL and BGU-WRRC are associated contractors in the project.

\section{REFERENCES}

[1] Tauer W. and G. Humborg, 1992, Runoff Irrigation in the Sahel Zone, Verlag Josef Margraf, Weikersheim, Germany, ISBN 3-8236-1212-3.

[2] Woolhizer D.A., Smith R.E. and D.C. Goodrich, 1990, KINEROS: a kinematic runoff and erosion model. Documentation and User Manual, USDA-ARS-77, 130.

[3] Holecz F., E. Meier, J. Piesbergen et al, 1994, Radiometric Calibration of Airborne SAR Imagery, Proc. IGARSS 94 Sym., Pasadena, USA. 